\title{
A Necropolítica Genocida de Bolsonaro em tempos de Pandemia e o Projeto Ultra-Neoliberal $^{1}$
}

\section{The Genocidic Necropolitics of Bolsonaro In Pandemic Times and the Ultra-Neoliberal Project}

\author{
LUANA ROSÁRIO \\ Doutora em Direito Público pela UFBA. \\ Professora Adjunta de Direito Constitucional da UESC. \\ lpdrosario@gmail.com
}

\section{RESUMO}

Este artigo questiona como a pandemia do Covid-19 evidencia o substrato que sustenta o projeto ultra-neoliberal do governo Bolsonaro, sob as estruturas do colonialismo, racismo e cis-hetero-patriarcado que degrada os indesejáveis e o próprio Estado democrático de direito. Numa proposta de ecologia dos saberes, alia a sociologia das ausências e do direito à necropolítica, à análise de discurso bakthianiana de origem marxista e utilizará das técnicas de pesquisa bibliográfica e documental.

Palavras-chave: Covid-19. Ultra-neoliberalismo. Colonialismo. Racismo. Cis-hetero-patriarcado. Necropolítica. Neo-fascismo.

\begin{abstract}
It questions how the Covid pandemic19 highlights the substrate that supports the ultra-neoliberal project of the Bolsonaro government, under the structures of colonialism, racism and cis-hetero-patriarchy that degrades the undesirable and the democratic state itself. In a proposal for the ecology of knowledge, it combines the sociology of absences and the right to necropolitics, with the analysis of Bakthian discourse of Marxist origin and will use the techniques of bibliographic and documentary research.
\end{abstract}

Keywords: Covid-19. Ultra-neoliberalism. Colonialism. Racism. Cis-hetero-patriarchy. Necropolitics. Neofascism.

"Se a esquerda radicalizar a esse ponto,

a gente vai precisar ter uma resposta.

E uma resposta pode ser via um novo AI-5".

(Eduardo Bolsonaro)

\section{INTRODUÇÃO}

Este ensaio busca refletir sobre como a agenda ultra-neoliberal encontra no governo Bolsonaro uma potente expressão ao aliar-se ao neofascismo, ao conservadorismo dos costumes, ao racismo e ao cis-hetero-patriarcado, viabilizados e potencializados pelo estabelecimento de um Estado de exceção que se assenta nos interesses de parcela da

\footnotetext{
${ }^{1}$ Artigo submetido para avaliação em 04/06/2020 e aprovado em 25/10/2020.
} 
Rev. Interd. em Cult. e Soc. (RICS), São Luís, v. 6, n. 2, p. 28-49, jul./dez. 2020

ISSN eletrônico: $2447-6498$

sociedade. Pondera como, num país que sofre severamente os danos do colonialismo, que se refletem num histórico constitucional autoritário, o golpe de Estado de 2016 possibilitou a chegada deste projeto ao poder. Questiona como a pandemia do Covid-19 evidencia a realidade subjacente à produção da degradação dos indesejáveis em um projeto de poder e de sociedade em que algumas pessoas importam menos do que outras e em que o lucro dos mercados é a prioridade do Estado para o enriquecimento daqueles que historicamente se beneficiam da exploração e do extermínio.

A perspectiva epistemológica deste trabalho é o das epistemologias do sul e da ecologia dos saberes, aliada à análise de discurso bakthianiana de origem marxista. Terá como marcos teóricos a articulação entre a sociologia das ausências de Boaventura de Sousa Santos, a sociologia o direito, de Casimiro Ferreira e a necropolítica de Achille Mbembe. Volta-se sobre a análise dos recentes acontecimentos políticos fartamente noticiados pela mídia a partir da literatura anunciada, aproximando-se de um fazer arqueologista, para o qual serão necessárias as técnicas de pesquisa bibliográfica e documental. Sua relevância teórica e pertinência social é o de intentar contribuir para a investigação da crise em que vivemos.

\section{O GOLPE DE ESTADO E O ESTADO DE EXCEÇÃO}

Sob a marca do colonialismo, a História Constitucional Brasileira é marcada por Constituições estabelecidas e substituídas por autoritarismo e Golpes de Estado, intrinsecamente relacionados com as disputas econômicas das elites. Países que foram colônias, mesmo após a independência, não raro se organizam de modo a perpetuar a acumulação violenta do capital das elites locais - que descendem, em sua maioria, dos colonizadores $^{2}$, uma vez que escravos e indígenas ${ }^{3}$ foram exterminados, excluídos ou tiveram o seu modo de vida criminalizado. Façamos um breve retrospecto da história constitucional brasileira, não em busca de linearidade histórica, mas, para evidenciar as contradições dialéticas que permeiam uma histórica política constitucional complexa e autoritária que culmina na eleição de um fascista, misógino, homofóbico, racista e imperialista ${ }^{4}$ para a presidência da República.

De início, nossa independência não resultou de um processo revolucionário popular, antes, foi declarada pelo regente português, que, uma vez imperador, dissolveu a Assembleia

\footnotetext{
${ }^{2}$ Ver MARIATÉGUI, José Carlos.Sete ensaios de interpretação da realidade peruana. São Paulo: Alfa Omega, 1975. E SOUZA, Jessé de. A elite do atraso: da escravidão à Lava-Jato. Leya, Rio de Janeiro: 2017.

${ }^{3}$ Ver C. F. Marés de Souza Filho (org.), Textos Clássicos sobre o Direito e os Povos Indígenas. Curitiba, Juruá / NDI, 1992.

${ }^{4}$ Entendido o imperialismo, em resumo, como relação de dominação/subjugação, uma relação de poder e influêcia, de dominação econômica e cultural de um país sobre outro, neste caso, a dominação norte-americana.
} 
Rev. Interd. em Cult. e Soc. (RICS), São Luís, v. 6, n. 2, p. 28-49, jul./dez. 2020 ISSN eletrônico: $2447-6498$

Constituinte e outorgou a Constituição de 1824. Por sua vez, a segunda Constituição do país e primeira republicana, foi fruto de uma República instaurada via um golpe de Estado, quando, muito em decorrência da abolição da escravatura, parcela do exército se aliou à elite cafeeira e traiu o monarca. A nossa Constituição Social de 1934, influenciada pela Constituição mexicana de 1917 e de Weimar, de 1919, foi promulgada durante um governo provisório, resultado do Golpe de 1930, que impediu a posse do presidente eleito, Luís Carlos Prestes. Substituída pela Constituição do Estado Novo, de 1937, de franca inspiração fascista, sob a qual Olga Binário, grávida, foi entregue para o campo de concentração nazista. Mesmo a Constituição de 1946, que reestabeleceu a democracia e os direitos políticos, resultou da eleição direta de ninguém menos do que do ministro da guerra de Getúlio Vargas, responsável, juntamente com o Alto Comando do Exército, pela deposição daquele. Uma linha do tempo autoritária que culmina no Golpe civil militar de 01 de abril de 1964, cujas marcas se sentem ainda hoje. Além de ter impedido as Reformas de Base, dentre as quais, a Reforma Agrária, desse período resultaram 17 atos institucionais e a Constituição de 1967, além da tortura, dos 'desaparecimentos forçados ${ }^{5}$ ' e mortes dos que se opuseram ao regime sem que tenha sido feita a justiça de transição.

A instauração do Estado Democrático Social e da festejada promulgação da “Constituição cidadã” de 1988, decorreu de uma abertura democrática "lenta, gradual e pacífica", um processo no qual houve a anistia geral e irrestrita aos agentes do antigo regime, em que se interditou a memória e se permitiu que o ovo da serpente do fascismo continuasse nas estruturas de Estado, para se eleger como atual presidente da República sob a égide da Constituição e o aparente funcionamento normal das instituições democráticas.

Atravessamos uma década de 90 de governos democráticos de inspiração neoliberal privatizadora. A partir de 2003, os três mandatos e meio (Lula/Lula/Dilma/Dilma) de governo popular de centro esquerda foi marcado por políticas públicas sociais que retirou 36 milhões de pessoas da pobreza extrema ${ }^{6}$, no qual o Brasil saiu do mapa da fome, o percentual de negros nas Universidades subiu consideravelmente ${ }^{7}$ mas, não foram feitas reformas estruturais no sistema financeiro ou no sistema tributário. Muito pouco foi feito em matéria de direitos de

\footnotetext{
${ }^{5}$ Embora seja termo utilizado em Convenção Internacional, o consideramos um eufemismo.

${ }^{6}$ JÚLIA. Após dez anos, governo atinge meta e retira 36 milhões da pobreza extrema. Rede Brasil Atual, 19 fev. 2013. Disponível em: <https://www.redebrasilatual.com.br/cidadania/2013/02/governo-federal-anuncia-medidade-erradicacao-da-extrema-pobreza/> . Acesso em: 13 maio 2020.

${ }^{7}$ ALFANO, Bruno; TATSCH, Constança; CAPETTI, Pedro. Negros são maioria pela primeira vez nas universidades públicas, aponta IBGE. O Globo, 13 nov. 2019. Disponível em: <https://oglobo.globo.com/sociedade/educacao/negros-sao-maioria-pela-primeira-vez-nas-universidadespublicas-aponta-ibge-24077731>. Acesso em: Acesso em: 12 maio 2020.
} 
Rev. Interd. em Cult. e Soc. (RICS), São Luís, v. 6, n. 2, p. 28-49, jul./dez. 2020

ISSN eletrônico: $2447-6498$

comunidades tradicionais, indígenas e quilombolas, e muito se reprimiu os movimentos sociais ${ }^{8}$.

É neste contexto que a crise econômico financeira mundial iniciada em 2008 cria as condições para o cenário político nacional convulsionar. A queda do preço das comodities no mercado internacional diminuiu a arrecadação do Estado e levou o governo a adotar medidas de austeridade. Os atores políticos representantes dos interesses do capital - do agronegócio ávido pela desregulamentação ambiental e dos arautos do livre mercado, interessados numa Reforma Trabalhista precarizadora, numa reforma previdenciária em prol dos interesses do sistema financeiro, e na mudança do regime de exploração proposto pelo partido dos Trabalhadores para o Pré-Sal $^{9}$ - aproveitam-se da insatisfação popular e da inaptidão conciliatória da presidenta Dilma Roussef para insuflar a mídia com notícias de corrupção do partido dos Trabalhadores, a fim de promover a remoção da presidenta eleita do Poder. A Operação Lava Jato, repleta de ilegalidades, violações de direitos fundamentais, evidente uso de Soft Law, personaliza em si as esperanças de cidadãos perdidos e carentes de referências simbólicas.

Setores econômicos da sociedade, representados no Congresso nacional e impulsionados pela mídia, além do visível elemento misógino ${ }^{10}$ nas relações de poder, articulam o golpimpeachment, um golpe parlamentar/judicial de Estado, diante da falta de configuração dos seus pressupostos constitucionais autorizadores e que se destinou à substituição de um projeto constitucional social democrata que ainda não concretizou suas garantias, para um projeto ultra-neoliberal em curso e que não tem amparo na Constituição de 1988. Não obstante a fragilidade das teses acusatórias e da chantagem declarada ${ }^{11} \mathrm{em}$ meios de comunicação do presidente da Câmara, a senhora Presidenta da República Dilma Vana Rousseff foi condenada, pelo Senado Federal, sob a tutela do Supremo Tribunal Federal, à perda do cargo, por, nos termos da sentença "contratar operações de crédito com instituição financeira controlada pela União e editar decretos de crédito suplementar sem autorização do Congresso Nacional”, sem a suspensão dos direitos políticos.

8 CARDOSO, Adrielly. O que é a Lei Antiterrorismo? Politize, 25 fev. 2019. Disponível em: <https://www.politize.com.br/lei-antiterrorismo/>. Acesso em: 12 maio 2020.

${ }^{9}$ REUTERS. Governo vai discutir fim do regime de partilha do pré-sal, diz ministro. R7, 06 nov. 2019. Disponível em: <https://noticias.r7.com/economia/governo-vai-discutir-fim-do-regime-de-partilha-do-pre-saldiz-ministro-06112019>. Acesso em: 14 maio 2020.

10 JANARA Kalline Leal Lopes de Sousa ... [et al.]; organização Elen Cristina Geraldes ... [et al.]. Mídia, Misoginia e Golpe 1. ed. - Brasília: FAC-UnB, 2016.

${ }^{11}$ URIBE, Gustavo; BRAGON, Ranier. Em retaliação a PT, Cunha ameaça deflagrar impeachment de Dilma Folha de São Paulo. Disponível em: http://www1.folha.uol.com.br/poder/2015/12/1714020-em-retaliacao-a-ptcunha-ameaca-deflagrar-impeachment-de-dilma.shtml. Acesso em: 14 maio 2020. 
Rev. Interd. em Cult. e Soc. (RICS), São Luís, v. 6, n. 2, p. 28-49, jul./dez. 2020 ISSN eletrônico: $2447-6498$

O vice-presidente Michel Temer, articulador do Golpe, do partido fisiológico com a maior bancada no Congresso - o PMDB, que remonta ao período ditatorial, intaurado pelo Ato Institucional $\mathrm{n}^{0} 2$ como $\mathrm{MDB}$ - assume para implantar o endurecimento do neoliberalismo. Lidera a aprovação da PEC do Fim do Mundo, promulgada pelo Congresso Nacional em dezembro de 2016. A Emenda Constitucional n. 95 limita as despesas públicas brasileiras, alcançando os três poderes, além do Ministério Público da União e da Defensoria Pública da União, pelo período de 20 anos. As despesas e investimentos públicos ficam limitadas aos mesmos valores gastos no ano anterior, corrigidos pela inflação. Em 2017, aprovou seu projeto de Reforma Trabalhista, alterando significativamente a Consolidação das Leis do Trabalho (CLT), no sentido da precarização e embaratecimento da mão de obra. As crises econômicas são utilizadas para implantar regimes de austeridade e cortes de direitos sociais, como se esta fosse a única alternativa existente diante da iminência de uma catástrofe social. Isso porque, salienta Casimiro Ferreira ${ }^{12}$, as alternativas sequer são discutidas e esse discurso de legitimação excepcional oculta que os sacrifícios não serão impostos a todos da mesma maneira. Como nos lembra Boaventura de Sousa Santos ${ }^{13}$, à medida que o neoliberalismo se impõe como versão dominante do capitalismo sujeita à lógica do setor financeiro o mundo passa a viver em permanente estado de crise.

\section{A AGENDA ULTRA-NEOLIBERAL E O NEO-FASCISMO}

Neste cenário, um deputado federal sem expressão na política nacional, Jair Messias Bolsonaro, começa a ganhar destaque com o seu discurso violento, simplista e negacionista da política. Foca principalmente no desejo do cidadão de ter segurança pública, na crítica à corrupção do governo e em pautas conservadoras. Sua crítica rasa ao funcionamento dos partidos, que não se aplica a ele próprio, que se beneficiou por décadas deste funcionamento, é visto por cidadãos desorientados como autêntico. Suas falas misóginas e homofóbicas dialogam com parcela conservadora considerável da sociedade. Sua atuação leva o movimento das mulheres a promoverem as maiores manifestações sociais recentes do país, o \#EleNão ${ }^{14}$. Depois de uma campanha presidencial marcada por fake news e por um esquema

\footnotetext{
12 FERREIRA, António Casimiro. Sociologia do Direito: uma abordagem sociopolítica. Vida Económica: Porto, 2019.

${ }^{13}$ SANTOS, Boaventura de Sousa. A cruel pedagogia do vírus. Coimbra, Almedina, 2020.

${ }^{14}$ ROSSI, Amanda; CARNEIRO, Julia Dias; GRAGNANI, Juliana. \#EleNão: A manifestação histórica liderada por mulheres no Brasil vista por quatro ângulos. BBC Brasil. Disponível em: https://www.bbc.com/portuguese/brasil-45700013. Acesso em: Acesso em: 14 maio 2020.
} 
Rev. Interd. em Cult. e Soc. (RICS), São Luís, v. 6, n. 2, p. 28-49, jul./dez. 2020 ISSN eletrônico: $2447-6498$

fraudelento financiado por empresas de disparo de mensagens pelo whats app ${ }^{15}$, que, não obstante, não levou a Justiça eleitoral a impugnar a chapa, é eleito presidente.

Militar, de extrema direita, Bolsonaro se diz contra a "velha política" ou contra "isso tudo que está aí”. Fazendo alusões aos valores tradicionais de deus, da família e do trabalho, apresenta um anti-esquerdismo conspiratório, que acusa a todos de comunistas. Apoiou a tentativa de golpe de Juan Guaidó na Venezuela, e o golpe contra Evo Morales, na Bolívia. A agenda ultra-neoliberal pode ser observada já pela nomeação do ultraliberal Paulo Guedes, partidário da Escola de Chicago, que lecionou no Chile durante a ditadura neoliberal de Pinochet, para titular do Ministério da Economia, que foi criado mediante a fusão dos ministérios da Fazenda, do Planejamento, Desenvolvimento e Gestão, da Indústria, Comércio Exterior e Serviços e parte do Ministério do Trabalho.

Bolsonaro personifica uma junção perigosa de neo fascismo com ultraneoliberalismo, uma nova extrema direita que, segundo Luiz Filgueiras e Graça Druck "consegue capturar a raiva e o ressentimento dos "perdedores" do processo de mundialização do capital dos últimos quarenta anos (conduzido pelas finanças e o ultra-neoliberalismo) e direcioná-los contra inimigos imaginários e o establishment em geral (a democracia liberal)."16 Segundo os autores, há uma clara convergência política, entre o ultraneoliberalismo, enquanto expressão dos interesses do capital financeiro e a atual ascensão da extrema-direita e neo-fascismo, pois as reformas agressivas e excludentes daquele acabam por colidir com o Estado de direito e com a democracia liberal, e a demandar um Estado de Exceção.

As principais plataformas ultraliberais do governo Bolsonaro levadas adiante até o momento foram a reforma previdenciária e a precarização da educação pública, especialmente do ensino superior, liderada por seu ministro da educação Abraham Weintraub. Embora as universidades públicas sejam responsáveis por mais de $90 \%$ das pesquisas realizadas no país ${ }^{17}$, bem como por serviços de saúde gratuitos. Em informações de 2019, em dados

\footnotetext{
${ }^{15}$ MELLO, Patrícia Campos. Empresários bancam campanha contra o PT pelo WhatsApp. Folha de São Paulo, 18 out. 2018. Disponível em:

$<$ https://www1.folha.uol.com.br/poder/2018/10/empresarios-bancam-campanha-contra-o-pt-pelowhatsapp.shtml>. Acesso em: 13 maio 2020.

${ }^{16}$ FILGUEIRAS, Luiz; DRUCK, Graça. O neoliberalismo neofascista do governo Bolsonaro e os desafios para a esquerda. Jornal GNN, 24 dez. 2019. Disponível em: <https://jornalggn.com.br/politica/o-neoliberalismoneofascista-do-governo-bolsonaro-e-os-desafios-para-a-esquerda/>. Acesso em: 13 maio 2020

${ }^{17}$ LOPES, José Reinaldo. Universidades públicas produzem mais de $90 \%$ da pesquisa do país; resta saber até quando. Folha de São Paulo, abr. 2019. Disponível em: <https://www1.folha.uol.com.br/colunas/reinaldojoselopes/2019/04/universidades-publicas-produzem-mais-de90-da-pesquisa-do-pais-resta-saber-ate-quando.shtml>. Acesso em: 13 maio 2020
} 
Rev. Interd. em Cult. e Soc. (RICS), São Luís, v. 6, n. 2, p. 28-49, jul./dez. 2020 ISSN eletrônico: $2447-6498$

levantados pela Consultoria de Orçamento da Câmara dos Deputados, ${ }^{18}$ o Ministério da Educação (MEC) tinha bloquedo $\mathrm{R} \$ 5,7$ bilhões, o que representa cerca de $23 \%$ de seu orçamento discricionário (não obrigatório), cortando verbas direcionadas a todas as etapas da educação. O congelamento de recursos comprometeu R $\$ 2,1$ bilhões das universidades ${ }^{19}$. Segundo relatório do Instituto de Estudos Socioeconômicos (Inesc) ${ }^{20}$ o congelamento atingiu fortemente as ações do Ministério da Educação (MEC) voltadas à redução das desigualdades educacionais, como a concessão de bolsa-permanência no ensino superior, que chegou a ter o orçamento zerado (assim como ações voltadas a exames de avaliação da Educação Básica, de Jovens e Adultos e profissionais). A medida prejudicou especialmente indígenas, quilombolas e estudantes de baixa renda, alunos cotistas, oriundos de escola pública.

Sua proposta de reforma previdenciária foi aprovada em novembro de 2019. Não alterou os direitos de quem já reuniu os requisitos para se aposentar e trouxe regras de transição para quem já está no mercado de trabalho. Em relação à proposta original encaminhada pelo governo, o Congresso, depois de muita pressão popular e dos movimentos sociais, não acatou a mudança para o regime de capitalização, as mudanças na aposentadoria de trabalhadores rurais, e alterações no pagamento do Benefício de Prestação Continuada (BPC) ao idoso ou à pessoa com deficiência. Além de aumentar o tempo para se aposentar ${ }^{21}$, a reforma elevou as alíquotas de contribuição para quem ganha acima do teto do INSS. Outro grande prejuízo para o trabalhador está no modo de cálculo do benefício. Pelas novas regras, o valor da aposentadoria será calculado com base na média de todo o histórico de contribuições do trabalhador (não descartando as $20 \%$ mais baixas, como feito atualmente). Ao atingir o tempo mínimo de contribuição (20 anos se for homem 15 se for mulher para aqueles que ingressarem no mercado de trabalho depois de aprovada a reforma), os trabalhadores do regime geral terão direito a apenas $60 \%$ do valor do benefício integral, com o percentual subindo 2 pontos para cada ano a mais de contribuição. Para ter direito a $100 \%$ da média dos salários, a mulher terá que contribuir por 35 anos e o homem, por 40 anos, um cenário

\footnotetext{
${ }^{18}$ MARIZ, Renata. Cortes no MEC afetam educação básica, anunciada como prioridade por Bolsonaro. O Globo, 06 maio 2020. Disponível em: <https://oglobo.globo.com/sociedade/cortes-no-mec-afetam-educacaobasica-anunciada-como-prioridade-por-bolsonaro-23646433>. Acesso em: 13 maio 2020

${ }^{19}$ A educação básica perdeu pelo menos R 914 milhões em políticas específicas para seu desenvolvimento. Isto numa realidade em que, segundo dados do Censo Escolar 2018 do Ministério da Educação (MEC) , apenas 42\% das escolas de ensino fundamental tem quadra, $68 \%$ tem pátio e $11 \%$ laboratórios de ciências e $5 \%$ de todas as escolas públicas do país ainda não tem banheiro.

${ }^{20}$ OLIVEIRA, Cida de. Educação é a área mais afetada pelos cortes de orçamento por Bolsonaro. Rede Brasil Atual, 19 jul. 2019. Disponível em: <https://www.redebrasilatual.com.br/educacao/2019/07/educacao-e-a-areamais-afetada-pelos-cortes-de-orcamento-por-bolsonaro/>. Acesso em: 13 maio 2020

${ }^{21}$ G1. Reforma da Previdência: entenda a proposta aprovada, ponto a ponto. G1, 22 out. 2019. Disponível em: <https://g1.globo.com/economia/noticia/2019/10/22/reforma-da-previdencia-entenda-ponto-a-ponto-a-propostaaprovada-em-2o-turno-no-senado.ghtml>. Acesso em: 13 maio 2020
} 
Rev. Interd. em Cult. e Soc. (RICS), São Luís, v. 6, n. 2, p. 28-49, jul./dez. 2020

ISSN eletrônico: $2447-6498$

improvável diante da expectativa de vida do brasileiro, sobretudo das camadas mais pobres da população.

Em sua agenda, Bolsonaro já anunciou que deseja privatizar os Correios, parques históricos, sistemas de água e esgoto e partes do sistema prisional. Bem como realizar uma reforma administrativa, que afetará a carreira do servidor público ${ }^{22}$, reduzirá a infraestrutura do estado e alterará a distribuição dos fundos do Estado para flexibilizar os gastos constitucionalmente obrigatórios em saúde e educação. Além de uma reforma tributária, que certamente, não inclui a taxação de grandes fortunas ou lucros e dividendos de grandes empresas. Deste modo, Bolsonaro é mandatário do desejo de reformas ultra-liberais do mercado que são difíceis de se realizar numa democracia saudável, pois contrárias à Constituição e ao interesse popular. Razão pela qual se viabilizam pela excepcionalidade de um regime que embora formalmente democrático, torna-se cada vez mais autoritário. Num fenômeno que Boaventura de Sousa Santos chama de democracia de baixa intensidade. Neste sentido, e dado o histórico da América latina, é elucidativo que nunca antes um governo teve tantos militares em seu primeiro escalão ${ }^{23}$.

\section{A NECROPOLÍTICA E O EXTERMÍNIO DOS INDESEJÁVEIS}

É neste cenário que a pandemia de Covid19 chega ao Brasil. Três meses depois de terem aparecido, em dezembro de 2019, os primeiros casos em Wuhan, na China, a covid-19 foi declarada pela OMS como pandemia em 11 de março de 2020, quando havia mais de 118 mil infectados em 114 países e 4291 mortes $^{24}$. Assustados com as notícias vindas da Itália ${ }^{25}$, os países do mundo discutiam com os especialistas como se preparar para enfrentar a pandemia e implantar o isolamento social -Portugal declara o estado de emergência, a Espanha estatizou os hospitais privados, a Alemanha aprovou pacote de 1,1 trilhão de euros e suspende a política orçamental de défice zero - no Brasil, as declarações do presidente, são

\footnotetext{
22 Iinclusive tendo aproveitado a pandemia de Covid19 para aprovar o congelamento remuneratório dos servidores públicos federais até 31 de dezembro de 2021. Ver: OLIVEIRA, Larissa Rodrigues de; OLIVEIRA, José Norberto Pinheiro de. Essa conta não é do servidor público: PLP 39/2020 e o congelamento de salários. Migalhas. Disponível em: https://www.migalhas.com.br/depeso/326531/essa-conta-nao-e-do-servidor-publicoplp-39-2020-e-o-congelamento-de-salarios. Acesso em: 13 de maio de 2020.

${ }^{23}$ OLIVEIRA, Germano. Governo fardado. Istoé, 21 fev. 2020. Disponível em: < https://istoe.com.br/governofardado/>. Acesso em: 13 de maio de 2020.

${ }^{24}$ MENDES, Filipa Almeida. OMS declara pandemia que exige "acções urgentes e agressivas" dos países. Público, 11 mar. 2020. Disponível em: <https://www.publico.pt/2020/03/11/ciencia/noticia/oms-declarapandemia-exige-accoes-urgentes-agressivas-paises-1907364>. Acesso em: 13 de maio de 2020.

${ }^{25}$ PACHO, Lorena. A dilacerante situação de Bergamo, a cidade italiana que não tem como cremar seus mortos. El País, 20 mar. 2020. Disponível em: <https://brasil.elpais.com/internacional/2020-03-19/bergamo-naoconsegue-enterrar-seus-mortos-e-exercito-leva-corpos-para-cremacao-em-outras-cidades.html>. Acesso em: 13 de maio de 2020.
} 
Rev. Interd. em Cult. e Soc. (RICS), São Luís, v. 6, n. 2, p. 28-49, jul./dez. 2020 ISSN eletrônico: $2447-6498$

assustadoras. Bolsonaro minimiza a pandemia, enfrenta os governadores que implantaram o isolamento social, e contraria seu próprio ministro da saúde ${ }^{26}$, que é demitido em plena crise. Enquanto o seu filho, o deputado federal Eduardo Bolsonaro ${ }^{27}$, no twitter, culpabiliza a China pela pandemia e o ministro da educação, Abraham Weintraub ${ }^{28}$, no twitter, acusa o país oriental de se beneficiar da pandemia. Acusações que além de estremecerem as relações diplomáticas com o maior parceiro comercial do Brasil, são xenofóbas, racistas, subservientes ao imperialismo norte-americano e em sua arrogância conspiratória não atentam para a realidade de que não somos invulneráveis.

Algumas afirmações de representantes da elite brasileira são ilustrativas para perceber como o bolsonarismo se enraiza numa sociedade extremamente desigual marcada pelo colonialismo escravocrata e racista. O empresário Junior Durski, dono dos restaurantes da rede Madero, ao criticar medidas restritivas impostas pelos governadores, afirmou que o Brasil não podia parar por 5 ou 7 mil mortes ${ }^{29}$. Roberto Justus afirmara que " Na favela não vai acontecer porra nenhuma se entrar o vírus, muito pelo contrário." ${ }^{30}$ No entanto, a primeira vítima fatal ${ }^{31}$ do Covid, no Brasil, no dia 17 de março, foi um porteiro, em São Paulo. No Rio de Janeiro, o primeiro óbito, em 19 de março, foi o de uma empregada doméstica, que não tinha sido dispensada do trabalho enquanto a patroa que havia voltado da Itália aguardava o resultado do teste ${ }^{32}$. Enquanto a Brasilândia com 89 casos confirmados da doença teve 54 mortes confirmadas ou suspeitas de coronavírus, o Morumbi, com 297 pessoas confirmadas,

${ }^{26}$ BENITES, Afonso; JUCÁ, Beatriz; BORGES, Rodolfo. Mandetta é demitido por Bolsonaro. El País, 16 abr. 2020. Disponível em: <https://brasil.elpais.com/sociedade/2020-04-16/mandetta-e-demitido-porbolsonaro.html>. Acesso em: 12 de maio de 2020.

${ }^{27}$ PARAGUASSU, Lisandra. Eduardo Bolsonaro abre crise com a China ao responsabilizar país por epidemia. Universo Online, 18 mar. 2020. Disponível em: <https://noticias.uol.com.br/ultimasnoticias/reuters/2020/03/18/eduardo-bolsonaro-abre-crise-com-a-china-ao-responsabilizar-pais-por-

epidemia.htm>. Acesso em: 14 de maio de 2020.

${ }^{28}$ SOARES, Manuela Goucha. Covid-19. China quer que Brasil peça desculpas das afirmações "racistas" do ministro da Educação. Expresso, 07 abr. 2020. Disponível em: <https://expresso.pt/coronavirus/2020-04-07Covid-19.-China-quer-que-Brasil-peca-desculpas-das-afirmacoes-racistas-do-ministro-da-Educacao〉. Acesso em: 14 de maio de 2020.

${ }^{29}$ PRAGMATISMO POLÍTICO. Brasil não pode parar "por 5 ou 7 mil mortes", diz dono do Madero. Pragmatismo Político, 24 mar. 2020. Disponível em: <https://www.pragmatismopolitico.com.br/2020/03/brasilnao-pode-parar-por-5-ou-7-mil-mortes-diz-dono-do-

madero.html?fbclid=IwAR3GzaXEP3d6oxc8cFKIjyDbFhWQ4LG5cUMBBjijCI_tpxolFtQpWhFRaQI>. Acesso em: 13 de maio de 2020.

30 PRAGMATISMO POLÍTICO. Áudio desumano de Roberto Justus sobre o coronavírus choca a internet. Pragmatismo Político, 22 mar. 2020. Disponível em: <https://www.pragmatismopolitico.com.br/2020/03/audioroberto-justus-coronavirus.html $>$. Acesso em: 13 de maio de 2020.

${ }^{31}$ PRAGMATISMO POLÍTICO. O desespero da família do primeiro morto no Brasil por coronavírus. Pragmatismo Político, 19 mar. 2020. Disponível em: <https://www.pragmatismopolitico.com.br/2020/03/odesespero-da-familia-do-primeiro-morto-no-brasil-por-coronavirus.html >. Acesso em: 13 de maio de 2020.

32 PRAGMATISMO POLÍTICO. Doméstica que não foi dispensada pela patroa morreu por coronavírus, diz exame. Pragmatismo Político, 19 mar. 2020. Disponível em: <https://www.pragmatismopolitico.com.br/2020/03/domestica-que-nao-foi-dispensada-pela-patroa-morreu-porcoronavirus-diz-exame.html>. Acesso em: 13 de maio de 2020. 
Rev. Interd. em Cult. e Soc. (RICS), São Luís, v. 6, n. 2, p. 28-49, jul./dez. 2020 ISSN eletrônico: $2447-6498$

teve sete mortes no mesmo período ${ }^{33}$. Na lógica colonial contemporânea, as pessoas que irão morrer não importam, até porque a maior parte delas é negra ${ }^{34}$.

Enquanto o vírus atinge mais as populações vulneráveis, o Estado, que deveria protege-las, age no sentido inverso. Na disputa com os governadores, em 21 de março Bolsonaro editou a Medida Provisória 926/20 pela qual somente o presidente teria competência para o fechamento de aeroportos e rodovias federais, além de manter na órbita federal serviços como o funcionamento de hospitais e laboratórios, transporte intermunicipal e interestadual, distribuição de água, tratamento de esgoto, serviços funerários, redes bancárias, entre outros. A questão foi levada pelo PDT - Partido Democrático Trabalhista - ao Supremo Tribunal Federal, que decidiu que a nova redação dada pela MP ao artigo $3^{\circ}$ da Lei federal $n^{\circ}$ 9.868/1999, não afasta a tomada de providências normativas e administrativas pelos Estados, Distrito Federal e Municípios.

$\mathrm{Na}$ mesma linha ultra-neoliberal, em 23 de março o governo Bolsonaro editou a Medida Provisória 927/20, que além de regulamentar o teletrabalho, previa, inicialmente, a possibilidade de suspensão dos contratos de trabalho sem o pagamento de salários, medida que foi derrogada após ampla pressão popular e do Congresso.Na mesma data, o Banco Central anunciou que iria injetar, no sistema financeiro, recursos que totalizariam R\$1,216 trilhão ${ }^{35}$, sem exigir nenhum vínculo com garantias sociais dos tomadores finais e intermediários.

Oportunamente, no mesmo dia, foi divulgado um estudo ${ }^{36}$ da Federação Nacional do Fisco Estadual e Distrital (Fenafisco), Associação Nacional dos Auditores Fiscais da Raceita Federal do Brasil (Anfic), os Auditores Fiscais pela Democracia (AFD), e o Instituto Justiça Fiscal (IJF), que demonstra que a tributação dos super-ricos poderia trazer 272 bilhões para enfrentar a crise. Os recursos viriam da criação de impostos como o Imposto sobre Grandes

\footnotetext{
${ }^{33}$ RODRIGUES, Rodrigo; BORGES, Beatriz; FIGUEIREDO, Patrícia. Morumbi tem mais casos de coronavírus e Brasilândia mais mortes;óbitos crescem 60\% em uma semana em SP. G1, 18 abr. 2020. Disponível em: <https://g1.globo.com/sp/sao-paulo/noticia/2020/04/18/morumbi-tem-mais-casos-de-coronavirus-e-brasilandiamais-mortes-obitos-crescem-60percent-em-uma-semana-em-sp.ghtml>. Acesso em: 14 de maio de 2020.

${ }^{34}$ VALOR ONLINE. Coronavírus é mais letal entre negros no Brasil, apontam dados do Ministério da Saúde. G1, 11 abr. 2020. Disponível em: <https://g1.globo.com/bemestar/coronavirus/noticia/2020/04/11/coronavirus-emais-letal-entre-negros-no-brasil-apontam-dados-do-ministerio-da-saude.ghtml>. Acesso em: 14 de maio de 2020.

${ }^{35}$ MARTELLO, Alexandro. BC anuncia nova liberação de recursos para os bancos; impacto total pode chegar a R \$1,2 trilhão. G1, 23 mar. 2020. Disponível em: <https://g1.globo.com/economia/noticia/2020/03/23/bc-mudacompulsorio-e-libera-temporariamente-r-68-bilhoes-ao-mercado-financeiro.ghtml>. Acesso em: 14 de maio de 2020.

${ }^{36}$ SAKAMOTO, Leonardo. Covid-19: Taxar super-rico traria $\mathrm{R} \$ 272$ bi contra crise, dizem entidades. Universo Online, 23 mar. 2020. Disponível em: <https://noticias.uol.com.br/colunas/leonardosakamoto/2020/03/23/coronavirus-taxar-super-rico-trara-r-272-bi-contra-crise-dizem-

entidades.htm?fbclid=IwAR15xHIDqIdKM1mtGnPcNpfJb6Tt-ByswPR-welfvwkf6S44fTyW2AspdN8>. Acesso em: 14 de maio de 2020.
} 
Rev. Interd. em Cult. e Soc. (RICS), São Luís, v. 6, n. 2, p. 28-49, jul./dez. 2020 ISSN eletrônico: $2447-6498$

Fortunas, a Contribuição Social Sobre Altas Rendas das Pessoas Físicas, a Contribuição Social Sobre o Lucro Líquido (CSLL) sobre os setores financeiro e extrativista mineral, e do Imposto de Renda sobre lucros e dividendos distribuídos a pessoas físicas. Mas esta não é uma escolha feita pelo ultra-neoliberalismo. A extrema-direita e a direita ultra-neoliberal, no mundo, não mostraram condições de lidar com a pandemia. Ela requer mais Estado, imprescinde de sistemas nacionais públicos de saúde bem equipados, a despeito do desmonte neoliberal pelo qual passaram nas últimas décadas neoliberais.

A inépcia do governo Bolsonaro para lidar com a pandema do Covid, a minimização do vírus, a negação da ciência, a estratégia discursiva de polarizar economia e vida, a inexistência de medidas por parte do governo federal à semelhança das que foram adotadas em outros países - como a nacionalização ou requisição de leitos de UTI privados, a utilização da indústria nacional para a produção de material médico e hospitalar, o auxílio aos governos estaduais na construção de hospitais de campanha, a proteção ao emprego, a garantia de prestações assistenciais de renda mínima, aprovada pelo congresso com resistência do governo - não é por acaso. Para o neoliberalismo, as vidas são descartáveis. Bolsonaro tem acesso aos estudos, aos dados, às projeções, à experiência internacional. Ele sabe quantas pessoas podem morrer pela Covid-19. A verdade é que para ele e o seu projeto, isso não importa.

Antonio Casimiro Ferreira ${ }^{37}$ descortina que no bojo desta reflexão está a questão de como o neoliberalismo financeiro se radicalizou em medidas privativas da afirmação humanista dos indivíduos, tem entrado em conflito com os direitos fundamentais e com a própria democracia. Há uma financeirização do mundo, uma crise, que não se limita ao setor econômico, mas que se estende à cultura, à civilização e à humanidade. Estamos diante de um modelo político-jurídico de desgaste dos direitos fundamentais e das expectativas sociais e normativas que lhes estão subjacentes. Em que são precarizados os próprios pressupostos da democracia liberal. Em tempos de austeridade, as funções do Estado social são substituídas pelas do Estado penal. Nesta lógica perversa "Os mercados são demasiado importantes para falhar e as pessoas demasiado irrelevantes para contar”. (FERREIRA, 2019, p. 341).

Essa indiferença é explícita nas falas de Bolsonaro. Em 24/03, Bolsonaro faz um pronunciamento nacional $^{38}$ no qual afirmou que o coronavírus se trata de uma "gripezinha",

\footnotetext{
${ }^{37}$ FERREIRA, António Casimiro. Sociologia do Direito: uma abordagem sociopolítica. Vida Económica: Porto, 2019.

${ }^{38}$ UNIVERSO ONLINE. 'Gripezinha': leia a íntegra do pronunciamento de Bolsonaro sobre covid-19. Universo Online, 24 mar. 2020. Disponível em: <https://noticias.uol.com.br/politica/ultimas-noticias/2020/03/24/leia-opronunciamento-do-presidente-jair-bolsonaro-na-integra.htm>. Acesso em: 14 de maio de 2020.
} 
Rev. Interd. em Cult. e Soc. (RICS), São Luís, v. 6, n. 2, p. 28-49, jul./dez. 2020

ISSN eletrônico: $2447-6498$

criticou governadores por determinarem quarentena - com fechamento de comércio e fronteiras - questionou o motivo pelo qual escolas foram fechadas e acusou a imprensa de produzir histeria infundada. Em 26 de março, Bolsonaro disse à imprensa brasileira, em frente ao Palácio da Alvorada: "Eu acho que não vai chegar a esse ponto [situação dos Estados Unidos]. Até porque o brasileiro tem que ser estudado. Ele não pega nada. O sujeito pula num esgoto e sai mergulhando, não acontece nada com ele". ${ }^{39} \mathrm{Em} 20$ de abril, quando o Brasil registrava 2.575 mortes e 40.581 casos confirmados de pessoas contaminadas pelo coronavírus, ao ser perguntado acerca do número de mortes por um jornalista, Bolsonaro respondeu: "Eu não sou coveiro, tá certo?"40. Em 28 de abril, quando o Brasil ultrapassou a China em número de mortes, tendo 5.017 mortos - números que não levam em conta a subnotificação, uma vez que o país não tem realizado testes, e as mortes por síndromes respiratórias aumentaram mais de $1.000 \%$, em alguns estados, mais de $6.000 \%{ }^{41}$, Jair Bolsonaro disse: "E daí? Lamento. Quer que eu faça o quê? Eu sou Messias, mas não faço milagre $^{42 "}$.

Não são apenas afirmações irrefletidas inconsequentes. Desvelar o discurso é imprescindível para compreender a complexidade das interações sociais e a própria constituição do sujeito social. Com Bakhtin ${ }^{43}$ aprendemos que a língua não é uma enunciação abstrata, monológica, mas se realiza na interação verbal, na experiência com o outro. A experiência da linguagem é social, o diálogo com o outro é constitutivo da linguagem. As falas de Bolsonaro são atravessadas pelo emaranhado de experiências sociais constituídas no colonialismo, racismo e cis-hetero-patriarcado. Suas falas trazem à tona a experiência de todos os outros sujeitos históricos e presentes que constituem o seu discurso e a quem ele se endereça em movimento dialógico, constituindo e sendo contituído pelas inúmeras discriminações sociais que externaliza, uma heterogeneidade constitutiva não visível. Sendo a consciência social, seu discurso é o processo de monologização das vozes do espaço social, não obstante sua tentativa de exclusão

\footnotetext{
${ }^{39}$ LUSA. Coronavírus: Bolsonaro volta a subestimar pandemia e diz que nada acontece com brasileiros. Público, 27 mar. 2020. Disponível em: <https://www.publico.pt/2020/03/27/mundo/noticia/coronavirus-bolsonaro-voltasubestimar-pandemia-nada-acontece-brasileiros-1909754>. Acesso em: 13 de maio de 2020.

${ }^{40}$ GOMES, Pedro Henrique. 'Não sou coveiro, tá?', diz Bolsonaro ao responder sobre mortos por coronavírus. G1, 20 abr. 2020. Disponível em: <https://g1.globo.com/politica/noticia/2020/04/20/nao-sou-coveiro-ta-dizbolsonaro-ao-responder-sobre-mortos-por-coronavirus.ghtml>. Acesso em: 13 de maio de 2020.

${ }^{41}$ CATRACA LIVRE. Mortes por síndromes respiratórias aumentam mais de $1.000 \%$ no Brasil. Catraca Livre, 28 abr. 2020. Disponível em: 12 de maio de 2020.

<https://catracalivre.com.br/saude-bem-estar/mortes-por-sindromes-respiratorias-aumentam-mais-de-1-000-nobrasil/amp/?fbclid=IwAR0Z851GyXZEN0xOMveMKO-xRW1JXMbwreARuTjpM0_7ylcjQ4EkWF9-wc4>. Acesso em:

${ }^{42}$ CHAIB, Julia; CARVALHO, Daniel. 'E daí? Lamento, quer que eu faça o quê?', diz Bolsonaro sobre recorde de mortos por coronavírus. Folha de São Paulo, 28 abr. 2020. Disponível em: <https://www1.folha.uol.com.br/equilibrioesaude/2020/04/e-dai-lamento-quer-que-eu-faca-o-que-diz-bolsonarosobre-recorde-de-mortos-por-coronavirus.shtml>. Acesso em: 12 de maio de 2020.

${ }^{43}$ BAKHTIN, M. Marxismo e Filosofia da Linguagem. 6. ed. São Paulo: Hucitec, 1992,
} 
Rev. Interd. em Cult. e Soc. (RICS), São Luís, v. 6, n. 2, p. 28-49, jul./dez. 2020

ontológica e discursiva daqueles que no processo social são excluídos. Elucidativas, neste ponto, as falas de ministros e do próprio Bolsonaro em vídeo de reunião ministerial divulgado enquanto este trabalho era finalizado, em 22 de maio, pelo ministro Celso de Mello, do Supremo Tribunal Federal. O vídeo faz parte do inquérito que investiga tentativa de interferência de Jair Bolsonaro na Polícia Federal. Sao falas que vocalizam discriminações sociais históricas e promovem a exclusão ontológica do outro, que se evidenciam no discurso. É notável, neste particular, a fala de Weintraub, ministro da educação: "Ele tá querendo transformar a gente numa colônia. Esse país não é... odeio o termo 'povos indígenas', odeio esse termo. Odeio. O 'povo cigano'. Só tem um povo nesse país. Quer, quer. Não quer, sai de ré"44. A conjugação das falas demonstra a junção do autoritarismo à visão ultra-neoliberal e tem em comum um recurso pelo qual aquele que perpetra a exclusão e a violência se coloca como vítima do excluído. O mesmo Weintraub sugeriu a prisão dos ministros do STF. Damares Alves, ministra da Mulher, da Família e dos Direitos Humanos, defendeu prender governadores e prefeitos após a pandemia. Ricardo Salles, do Meio Ambiente, sugeriu aproveitar o foco da mídia na pandemia para fazer fragilizar a legislação ambiental. Paulo Guedes, da Economia, defendeu a venda do Banco do Brasil. Enquanto Bolsonaro sugeriu armar a população contra os governadores.

O governo Bolsonaro revela a ligação cruel que se estabelece entre colonialismo, neoliberalismo e estado de exceção, evidenciam como os propósitos expoliadores do neoliberalismo se utilizam do estado de exceção e a tônica que isto adquire em país atravessado por um passado colonial que se mantém. Uma concepção econômica perversa que requer da política não a preservação de pessoas ou de direitos, como no ideário humanista ou do Estado Social, pelo contrário, está desconcertantemente relacionada à dominação e à morte. Podemos fazer uso aqui da noção de Achille Mbembe ${ }^{45}$ de necropolítica. Mbembe faz a leitura da necropolítica no bojo do colonialismo passado e presente, uma vez que o colonialismo permanece realizando suas exclusões nos dias atuais. "Em muitos aspectos, a própria estrutura do sistema de colonização e suas consequências manifesta a figura emblemática e paradoxal do estado de exceção”. (p 130). Esse estado de exceção serve muito bem aos propósitos neoliberais.

\footnotetext{
${ }^{44}$ ESTADÃO. Veja as principais falas de Bolsonaro e ministros em reunião divulgada pelo STF. Estadão. Disponível em: https://politica.estadao.com.br/noticias/geral,veja-as-principais-falas-de-bolsonaro-e-ministrosem-reuniao-divulgada-pelo-stf,70003311895. Acessado em: 23 maio 2020.

${ }^{45}$ MBEMBE, Achille. Necropolítica. Arte \& Ensaios, PPGAV, EBA, UFRJ, n.32, dez. 2016.
} 
Rev. Interd. em Cult. e Soc. (RICS), São Luís, v. 6, n. 2, p. 28-49, jul./dez. 2020

Segundo Boaventura de Sousa Santos ${ }^{46}$, a modernidade em que vivemos é dividida por uma linha invisivel, a linha abissal. Esta distinção invisível é a distinção entre as sociedades metropolitanas e os territórios coloniais. Assim, a realidade social é dividida em dois universos distintos: o universo 'deste lado da linha' e o universo 'do outro lado da linha. As pessoas que estão do outro lado da linha abissal, na zona metropolitana sofrem uma degradação ontológica. São menos pessoas para o sistema que produz distinções invisiveis, tem menos direitos, importam menos. São aqueles que podem ser deixados para morrer.

Em Mbembe, a necropolítica é a forma contemporânea de subjugação a vida ao poder da morte, pela qual vastas populações são submetidas a condições de vida que lhes conferem o status de mortos-vivos. A partir da noção de biopoder de Foucault, que ele denomina como "aquele domínio da vida sobre o qual o poder tomou o controle" (p. 123), questiona sob quais condições práticas se exerce o direito de matar, deixar viver ou expor à morte. É exatamente o qe faz Bolsonaro, decide expor à morte ou deixar morrer milhares de brasileiros sem que políticas públicas de enfrentamento à pandemia sejam tomadas. Para o autor, o poder apela à exceção, emergência e a uma noção ficcional do inimigo, de modo que “o estado de exceção e a relação de inimizade tornaram-se a base normativa do direito de matar" (MBEMBE, 2016, p. 128). O discurso de Bolsonaro é povoado de inimigos. São inimigos a imprensa, a esquerda, os comunistas, a Universidade, a ciência, os "bandidos", uma vez que “[...] os caras vão morrer na rua igual barata, pô. E tem que ser assim ${ }^{47}$." Como em Mbembe, "a soberania é a capacidade de definir quem importa e quem não importa, quem é “descartável” e quem não é”. (MBEMBE, 2016, p. 135).

Conforme destacam Luiz Filgueiras e Graça Druck, a extrema-direita contemporânea, neofascista, dá ao capital financeiro e a sua expressão político-ideológica (o neoliberalismo) uma massa de apoio sensibilizada, por valores morais e culturais retrógrados e pelo fundamentalismo religioso. Bolsonaro surge como aquele que aglutina os ressentidos pelo medo contra o outro: o imigrante, o comunista, o nordestino, o gay, o negro, a mulher, o artista, o intelectual, o professor, o político, o funcionário público. Não por acaso um dos movimentos que mais reagiu à sua eleição foi o movimento de mulheres. Justamente as mulheres que agora estão mais vulneráveis com o confinamento da pandemia que faz os

\footnotetext{
${ }^{46}$ SANTOS, Boaventura de Sousa. Para além do pensamento abissal: das linhas globais á ecologia dos saberes. In: Epistemologias do Sul.

${ }^{47}$ GOMES, Hélder. “Os caras vão morrer na rua igual barata, pô. E tem que ser assim”, diz Bolsonaro sobre criminosos. Expresso, 06 ago. 2019. Disponível em:

$<$ https://expresso.pt/internacional/2019-08-06-Os-caras-vao-morrer-na-rua-igual-barata-po.-E-tem-que-serassim-diz-Bolsonaro-sobre-criminosos>. Acesso em: 13 de maio de 2020.
} 
Rev. Interd. em Cult. e Soc. (RICS), São Luís, v. 6, n. 2, p. 28-49, jul./dez. 2020 ISSN eletrônico: $2447-6498$

números de violência doméstica dispararem no Brasil ${ }^{48}$. E a população preta, pobre e periférica, moradora de favelas, áreas em que é difícil ${ }^{49}$ fazer o distanciamento social ${ }^{50}$, regiões nas quas muitas vezes nem há água potável ou postos médicos. Não obstante sejam aqueles para quem é mais dificil fazer o isolamento e deixar de trabalhar, é onde o isolamento tem grande taxa de aprovação ${ }^{51}$. Onde o narcotráfico tem feito o trabalho do Estado ${ }^{52}$. Os sem teto, invibilizados do espaço social, que segundo Damares Alves, ministra da Mulher, da Família e dos Direitos Humanos, não contraem coronavírus porque "ninguém pega na mão deles"53. Embora o O MTST (Movimento dos Trabalhadores Sem Teto) tenha criado um fundo de solidariedade para comprar alimentos, medicamentos e produtos de limpeza e álcool gel para distribuir aos sem-teto por conta da pandemia. Diante da falta de políticas públicas, a solidariedade dos grupos vulneráveis, que segundo Boaventura de Sousa Santos ${ }^{54}$ estão a sul da quarentena, sul definido pelo autor como "[...] espaço-tempo político, social e cultural, metáfora do sofrimento humano injusto causado pela exploração capitalista, pela discriminação racial e pela discriminação sexual" nesta que é a tripla dominação da modernidade, o colonalismo, o capitalismo e o pariarcado.

O Bolsonarismo, advertem Luiz Filgueiras e Graça Druck, é um espectro emocional, anti-racional, anti-ciência que aglutina a si a pauta ultra-neoliberal do mercado, o conservadorismo neopentecostal e a direita militar tradicional, presente nos primeiros escalões do governo cuja presença simbólica é a ameaça do golpe pelas armas. Implanta-se um Estado de exceção não assumido que perpetra a perseguição e o extermínio de adversários políticos e de pessoas consideradas à margem da "normalidade". Vide o envolvimento de Bolsonaro com

\footnotetext{
${ }^{48}$ MAZZI, Carolina. Violência doméstica dispara na quarentena: como reconhecer, proteger e denunciar. O Globo, 01 maio 2020. Disponível em: <https://oglobo.globo.com/sociedade/coronavirus-servico/violenciadomestica-dispara-na-quarentena-como-reconhecer-proteger-denunciar-24405355>. Acesso em: 13 de maio de 2020.

${ }^{49}$ PÚBLICO. Coronavírus: quarentena nas favelas do Brasil agrava pobreza em apenas uma semana. Público, 25 mar. 2020. Disponível em: <https://www.publico.pt/2020/03/25/mundo/noticia/coronavirus-quarentena-favelasbrasil-agrava-pobreza-apenas-semana-1909380>. Acesso em: 13 de maio de 2020.

${ }^{50}$ ALENCAR, Eduardo Matos de. A vida nas favelas: como três comunidades - em São Paulo, Rio e Recife enfrentam a pandemia. Piauí, 23 abr. 2020. Disponível em: <https://piaui.folha.uol.com.br/vida-nas-favelas/>. Acesso em: 12 de maio de 2020.

51 VILLAS BÔAS, Bruno. Nas favelas, 71\% apoiam quarentena. Valor Econômico, 09 abr. 2020. Disponível em: <https://valor.globo.com/brasil/noticia/2020/04/09/nas-favelas-71-apoiam-quarentena.ghtml>. Acesso em:

${ }^{52}$ BLOIS, Caio. Tráfico impõe toque de recolher em favelas do Rio em meio a crise do corona. Universo Online, 24 mar. 2020. Disponível em: <https://noticias.uol.com.br/cotidiano/ultimas-noticias/2020/03/24/coronavirusfaccoes-do-trafico-impoem-toque-de-recolher-em-favelas-do-rj.htm>. Acesso em: 14 de maio de 2020.

${ }^{53}$ UNIVERSO ONLINE. Damares: poucos moradores de rua têm covid, pois ninguém pega na mão deles. Universo Online, 07 maio 2020. Disponível em: <https://noticias.uol.com.br/saude/ultimasnoticias/redacao/2020/05/07/damares-poucos-moradores-de-rua-tem-covid-pois-ninguem-pega-na-maodeles.htm>. Acesso em: 14 de maio de 2020.

${ }^{54}$ SANTOS, Boaventura de Sousa. A cruel pedagogia do vírus. Coimbra, Almedina, 2020.
} 
Rev. Interd. em Cult. e Soc. (RICS), São Luís, v. 6, n. 2, p. 28-49, jul./dez. 2020 ISSN eletrônico: $2447-6498$

as milícias ${ }^{55}$ e o surgimento do seu nome nas investigações do assassinato de Marielle Franco $^{56}$. Atitudes recentes de Bolsonaro mostram que sua prioridade neste momento não é combater a pandemia, mas interferir na Polícia Federal para assegurar a sua impunidade e de sua família ${ }^{57}$ e a negociata com o Centrão ${ }^{58}$ para frustrar seu impeachment. Levar a cabo este objetivo acena até para a possibilidade de autogolpe. À crise pandêmica no Brasil; que neste momento já chegou à marca dezessete mil mortos e mais de mil mortos por dia ${ }^{59}$; soma-se uma grave crise política que coloca em risco a democracia. À postura diante da pandemia do Covid19 conjugam-se a defesa da tortura e de torturadores, o ataque ao Estado de Direito, à Instituições científicas (IBGE, INPE, CNPq), o estrangulamento financeiro das Universidades Públicas, a violência armada contra os índios e movimentos sociais, o estímulo ao desmatamento da Amazônia. No que se revela, diante da crise, um projeto nefasto e perverso sobre o qual precisamos, enquanto sociedade, seriamente refletir, e, sobretudo, agir.

\section{CONSIDERAÇÕES FINAIS}

Bolsonaro sabe quantas pessoas podem morrer pelo Covid-19 e não se importa. O capitalismo financeiro também não se importa com isso porque o que interessa a seus representantes é a realização das reformas ultraliberais com as quais Bolsonaro se comprometeu. Enquanto os atores políticos tolerarem Bolsonaro em razão do projeto neoliberal, a democracia brasileira está sob grave risco. O governo Bolsonaro revela a ligação cruel que se estabelece entre colonialismo, neoliberalismo e estado de exceção, evidencia como os propósitos expoliadores do neoliberalismo se utilizam da excepcionalidade e a tônica que isto adquire em país atravessado por um passado colonial que se mantém.

A realidade da pandemia de Covid-19 em uma democracia débil, de passado e presente colonialista e escravocrata, racista, machista e cis-hetero-patriarcal é grave. Em um

\footnotetext{
55 OLLIVEIRA, Cecília. As ligações dos Bolsonaros com as milícias. The Intercept, 22 jan. 2019. Disponível em: <https://theintercept.com/2019/01/22/bolsonaros-milicias/>. Acesso em: 13 de maio de 2020.

${ }^{56}$ EXPRESSO. Nome de Bolsonaro surge na investigação da morte de Marielle Franco graças a depoimento de porteiro do condomínio onde vive. Expresso, 30 out. 2019. Disponível em: $<$ https://expresso.pt/internacional/2019-10-30-Nome-de-Bolsonaro-surge-na-investigacao-da-morte-de-MarielleFranco-gracas-a-depoimento-de-porteiro-do-condominio-onde-vive>. Acesso em: 13 de maio de 2020.

${ }^{57}$ KADANUS, Kelli. Por que a Polícia Federal é tão importante para Bolsonaro. Gazeta do Povo, 11 maio 2020. Disponível em: <https://www.gazetadopovo.com.br/republica/policia-federal-controle-importante-bolsonaro>. Acesso em:/ 13 de maio de 2020.

${ }^{58}$ SHALDERS, André. Cargos que Bolsonaro negocia com centrão têm mais de R \$ 10,6 bilhões 'livres' para investir em 2020. Universo Online, 29 abr. 2020. Disponível em: <https://noticias.uol.com.br/ultimasnoticias/bbc/2020/04/29/cargos-que-bolsonaro-negocia-com-centrao-tem-mais-de-r-106-bilhoes-livres-parainvestir-em-2020.htm>. Acesso em: 14 de maio de 2020.

${ }^{59}$ SANDES, Arthur. Com mais de mil mortes em um dia, Brasil tem um óbito a cada 73 segundos. Universo Online, 19 maio 2020. Disponível em: <https://noticias.uol.com.br/saude/ultimas-

noticias/redacao/2020/05/19/covid-19-mortes-por-segundo-no-brasil.htm>. Acesso em: 14 de maio de 2020.
} 
Rev. Interd. em Cult. e Soc. (RICS), São Luís, v. 6, n. 2, p. 28-49, jul./dez. 2020 ISSN eletrônico: $2447-6498$

país que anistiou os crimes cometidos durante a ditadura militar, é violenta. Em que as recentes conquistas populares no combate à desigualdade e à pobreza extrema se deram por meio de uma conciliação precária com as elites dominantes, é oportunista. Em um cenário global econômico ávido por reformas ultra-neoliberais, é insidiosa. Em país que acaba de sofrer um golpe parlamentar/judicial de Estado, é cínica. No qual se acentuam ao limite as medidas de austeridade, é pérfida. O projeto ultra-neoliberal desta nova extrema-direita pelas reformas trabalhista, previdenciária, tributária, administrativa, a qualquer custo, é de saque.

A pandemia de Covid-19, no Brasil, mostra que o sacrifício fatal da democracia é traiçoeiro e que pessoas, pelos diferentes motivos, por conservadorismo de costumes, por militarismo de caserna, por ressentimento mal direcionado, podem se aliar a um projeto desumano, perverso, cruel. Descortina a face oculta do mal. A omissão de políticas públicas de enfrentamento à pandemia e a indiferença diante dos milhares de mortos é fascista. Deixar morrer, no exercício da necropolítica, aqueles que se considera descartáveis, aqueles do outro lado da linha abissal, é vil. Não fazer nada, é covarde.

\section{REFERÊNCIAS}

ALENCAR, Eduardo Matos de. A vida nas favelas: como três comunidades - em São Paulo, Rio e Recife - enfrentam a pandemia. Piauí, 23 abr. 2020. Disponível em: <https://piaui.folha.uol.com.br/vida-nas-favelas/>. Acesso em: 12 maio 2020.

ALFANO, Bruno; TATSCH, Constança; CAPETTI, Pedro. Negros são maioria pela primeira vez nas universidades públicas, aponta IBGE. O Globo, 13 nov. 2019. Disponível em: $<$ https://oglobo.globo.com/sociedade/educacao/negros-sao-maioria-pela-primeira-vez-nasuniversidades-publicas-aponta-ibge-24077731>. Acesso em: 12 maio 2020.

BAKHTIN, M. Marxismo e Filosofia da Linguagem. 6. ed. São Paulo: Hucitec, 1992.

BENITES, Afonso; JUCÁ, Beatriz; BORGES, Rodolfo. Mandetta é demitido por Bolsonaro. El País, 16 abr. 2020. Disponível em: <https://brasil.elpais.com/sociedade/2020-0416/mandetta-e-demitido-por-bolsonaro.html>. Acesso em: 12 maio 2020.

BLOIS, Caio. Tráfico impõe toque de recolher em favelas do Rio em meio a crise do corona. Universo Online, 24 mar. 2020. Disponível em: $<$ https://noticias.uol.com.br/cotidiano/ultimas-noticias/2020/03/24/coronavirus-faccoes-dotrafico-impoem-toque-de-recolher-em-favelas-do-rj.htm>. Acesso em: 12 maio 2020.

CARDOSO, Adrielly. O que é a Lei Antiterrorismo? Politize, 25 fev. 2019. Disponível em: <https://www.politize.com.br/lei-antiterrorismo/>. Acesso em: 12 maio 2020.

CATRACA LIVRE. Mortes por síndromes respiratórias aumentam mais de 1.000\% no Brasil. Catraca Livre, 28 abr. 2020. Disponível em: <https://catracalivre.com.br/saude-bemestar/mortes-por-sindromes-respiratorias-aumentam-mais-de-1-000-no- 
Rev. Interd. em Cult. e Soc. (RICS), São Luís, v. 6, n. 2, p. 28-49, jul./dez. 2020

ISSN eletrônico: $2447-6498$

brasil/amp/?fbclid=IwAR0Z851GyXZEN0xOMveMKO-

xRWIJXMbwreARuTjpM0_7ylcjQ4EkWF9-wc4>. Acesso em: 12 maio 2020.

CHAIB, Julia; CARVALHO, Daniel. 'E daí? Lamento, quer que eu faça o quê?', diz

Bolsonaro sobre recorde de mortos por coronavírus. Folha de São Paulo, 28 abr. 2020.

Disponível em: <https://www1.folha.uol.com.br/equilibrioesaude/2020/04/e-dai-lamentoquer-que-eu-faca-o-que-diz-bolsonaro-sobre-recorde-de-mortos-por-coronavirus.shtml $>$. Acesso em: 12 maio 2020.

ESTADÃO. Veja as principais falas de Bolsonaro e ministros em reunião divulgada pelo STF. Estadão. Disponível em: https://politica.estadao.com.br/noticias/geral,veja-as-principaisfalas-de-bolsonaro-e-ministros-em-reuniao-divulgada-pelo-stf,70003311895. Acessado em: 23 maio 2020.

EXPRESSO. Nome de Bolsonaro surge na investigação da morte de Marielle Franco graças a depoimento de porteiro do condomínio onde vive. Expresso, 30 out. 2019. Disponível em: $<$ https://expresso.pt/internacional/2019-10-30-Nome-de-Bolsonaro-surge-na-investigacao-damorte-de-Marielle-Franco-gracas-a-depoimento-de-porteiro-do-condominio-onde-vive> . Acesso em: 13 maio 2020.

FERREIRA, António Casimiro. Sociologia do Direito: uma abordagem sociopolítica. Vida Económica: Porto, 2019.

FILGUEIRAS, Luiz; DRUCK, Graça. O neoliberalismo neofascista do governo Bolsonaro e os desafios para a esquerda. Jornal GNN, 24 dez. 2019. Disponível em:

$<$ https://jornalggn.com.br/politica/o-neoliberalismo-neofascista-do-governo-bolsonaro-e-osdesafios-para-a-esquerda/>. Acesso em: 13 maio 2020.

G1. Reforma da Previdência: entenda a proposta aprovada, ponto a ponto. G1, 22 out. 2019. Disponível em: <https://g1.globo.com/economia/noticia/2019/10/22/reforma-da-previdenciaentenda-ponto-a-ponto-a-proposta-aprovada-em-2o-turno-no-senado.ghtml >. Acesso em: 13 maio 2020.

GOMES, Hélder. "Os caras vão morrer na rua igual barata, pô. E tem que ser assim", diz Bolsonaro sobre criminosos. Expresso, 06 ago. 2019. Disponível em: $<$ https://expresso.pt/internacional/2019-08-06-Os-caras-vao-morrer-na-rua-igual-barata-po.E-tem-que-ser-assim-diz-Bolsonaro-sobre-criminosos>. Acesso em: 13 maio 2020.

GOMES, Pedro Henrique. 'Não sou coveiro, tá?', diz Bolsonaro ao responder sobre mortos por coronavírus. G1, 20 abr. 2020. Disponível em:

<https://g1.globo.com/politica/noticia/2020/04/20/nao-sou-coveiro-ta-diz-bolsonaro-aoresponder-sobre-mortos-por-coronavirus.ghtml>. Acesso em: 13 maio 2020.

JANARA Kalline Leal Lopes de Sousa ... [et al.];organização Elen Cristina Geraldes ... [et al.]. Mídia, Misoginia e Golpe 1. ed. - Brasília: FAC-UnB, 2016.

JÚLIA. Após dez anos, governo atinge meta e retira 36 milhões da pobreza extrema. Rede Brasil Atual, 19 fev. 2013. Disponível em:

$<$ https://www.redebrasilatual.com.br/cidadania/2013/02/governo-federal-anuncia-medida-deerradicacao-da-extrema-pobreza/>. Acesso em: 13 maio 2020. 
Rev. Interd. em Cult. e Soc. (RICS), São Luís, v. 6, n. 2, p. 28-49, jul./dez. 2020 ISSN eletrônico: 2447-6498

KADANUS, Kelli. Por que a Polícia Federal é tão importante para Bolsonaro. Gazeta do Povo, 11 maio 2020. Disponível em: <https://www.gazetadopovo.com.br/republica/policiafederal-controle-importante-bolsonaro>. Acesso em: 13 maio 2020.

LOPES, José Reinaldo. Universidades públicas produzem mais de 90\% da pesquisa do país; resta saber até quando. Folha de São Paulo, abr. 2019. Disponível em:

$<$ https://www1.folha.uol.com.br/colunas/reinaldojoselopes/2019/04/universidades-publicasproduzem-mais-de-90-da-pesquisa-do-pais-resta-saber-ate-quando.shtml>. Acesso em: 13 maio 2020.

LUSA. Coronavírus: Bolsonaro volta a subestimar pandemia e diz que nada acontece com brasileiros. Público, 27 mar. 2020. Disponível em: <https://www.publico.pt/2020/03/27/mundo/noticia/coronavirus-bolsonaro-volta-subestimarpandemia-nada-acontece-brasileiros-1909754>. Acesso em: 13 maio 2020.

MARIZ, Renata. Cortes no MEC afetam educação básica, anunciada como prioridade por Bolsonaro. O Globo, 06 maio 2020. Disponível em:

2020<https://oglobo.globo.com/sociedade/cortes-no-mec-afetam-educacao-basica-anunciadacomo-prioridade-por-bolsonaro-23646433>. Acesso em: 13 maio 2020.

MARTELLO, Alexandro. BC anuncia nova liberação de recursos para os bancos; impacto total pode chegar a R \$1,2 trilhão. G1, 23 mar. 2020. Disponível em: $<$ https://g1.globo.com/economia/noticia/2020/03/23/bc-muda-compulsorio-e-liberatemporariamente-r-68-bilhoes-ao-mercado-financeiro.ghtml>. Acesso em: 13 maio 2020.

MAZZI, Carolina. Violência doméstica dispara na quarentena: como reconhecer, proteger e denunciar. O Globo, 01 maio 2020. Disponível em:

$<$ https://oglobo.globo.com/sociedade/coronavirus-servico/violencia-domestica-dispara-naquarentena-como-reconhecer-proteger-denunciar-24405355>. Acesso em: 13 maio 2020. MBEMBE, Achille. Necropolítica. Arte \& Ensaios, PPGAV, EBA, UFRJ, n.32, dez. 2016.

MELLO, Patrícia Campos. Empresários bancam campanha contra o PT pelo WhatsApp.

Folha de São Paulo, 18 out. 2018. Disponível em:

$<$ https://www1.folha.uol.com.br/poder/2018/10/empresarios-bancam-campanha-contra-o-ptpelo-whatsapp.shtml>. Acesso em: 13 maio 2020.

MENDES, Filipa Almeida. OMS declara pandemia que exige "acções urgentes e agressivas" dos países. Público, 11 mar. 2020. Disponível em:

<https://www.publico.pt/2020/03/11/ciencia/noticia/oms-declara-pandemia-exige-accoesurgentes-agressivas-paises-1907364>. Acesso em: 13 maio 2020.

OLIVEIRA, Cida de. Educação é a área mais afetada pelos cortes de orçamento por Bolsonaro. Rede Brasil Atual, 19 jul. 2019. Disponível em: $<$ https://www.redebrasilatual.com.br/educacao/2019/07/educacao-e-a-area-mais-afetadapelos-cortes-de-orcamento-por-bolsonaro/>. Acesso em: 13 maio 2020.

OLIVEIRA, Germano. Governo fardado. Istoé, 21 fev. 2020. Disponível em: <https://istoe.com.br/governo-fardado/>. Acesso em: 13 maio 2020. 
Rev. Interd. em Cult. e Soc. (RICS), São Luís, v. 6, n. 2, p. 28-49, jul./dez. 2020 ISSN eletrônico: $2447-6498$

OLIVEIRA, Larissa Rodrigues de; OLIVEIRA, José Norberto Pinheiro de. Essa conta não é do servidor público: PLP 39/2020 e o congelamento de salários. Migalhas. Disponível em: https://www.migalhas.com.br/depeso/326531/essa-conta-nao-e-do-servidor-publico-plp-392020-e-o-congelamento-de-salarios. Acesso em: 13 de maio de 2020.

OLLIVEIRA, Cecília. As ligações dos Bolsonaros com as milícias. The Intercept, 22 jan. 2019. Disponível em: <https://theintercept.com/2019/01/22/bolsonaros-milicias/>. Acesso em: 13 maio 2020.

PACHO, Lorena. A dilacerante situação de Bergamo, a cidade italiana que não tem como cremar seus mortos. El País, 20 mar. 2020. Disponível em:

$<$ https://brasil.elpais.com/internacional/2020-03-19/bergamo-nao-consegue-enterrar-seusmortos-e-exercito-leva-corpos-para-cremacao-em-outras-cidades.html>. Acesso em: 13 maio 2020.

PARAGUASSU, Lisandra. Eduardo Bolsonaro abre crise com a China ao responsabilizar país por epidemia. Universo Online, 18 mar. 2020. Disponível em:

$<$ https://noticias.uol.com.br/ultimas-noticias/reuters/2020/03/18/eduardo-bolsonaro-abrecrise-com-a-china-ao-responsabilizar-pais-por-epidemia.htm>. Acesso em: 13 maio 2020.

PRAGMATISMO POLÍTICO. Áudio desumano de Roberto Justus sobre o coronavírus choca a internet. Pragmatismo Político, 22 mar. 2020. Disponível em:

<https://www.pragmatismopolitico.com.br/2020/03/audio-roberto-justus-coronavirus.html>. Acesso em: 13 maio 2020.

PRAGMATISMO POLÍTICO. Brasil não pode parar “por 5 ou 7 mil mortes”, diz dono do Madero. Pragmatismo Político, 24 mar. 2020. Disponível em:

$<$ https://www.pragmatismopolitico.com.br/2020/03/brasil-nao-pode-parar-por-5-ou-7-milmortes-diz-dono-do-

madero.html?fbclid=IwAR3GzaXEP3d6oxc8cFKIjyDbFhWQ4LG5cUMBBjijCI_tpxolFtQp WhFRaQI>. Acesso em: : 13 maio 2020.

PRAGMATISMO POLÍTICO. Doméstica que não foi dispensada pela patroa morreu por coronavírus, diz exame. Pragmatismo Político, 19 mar. 2020. Disponível em: $<$ https://www.pragmatismopolitico.com.br/2020/03/domestica-que-nao-foi-dispensada-pelapatroa-morreu-por-coronavirus-diz-exame.html>. Acesso em: 13 maio 2020.

PRAGMATISMO POLÍTICO. O desespero da família do primeiro morto no Brasil por coronavírus. Pragmatismo Político, 19 mar. 2020. Disponível em:

$<$ https://www.pragmatismopolitico.com.br/2020/03/o-desespero-da-familia-do-primeiromorto-no-brasil-por-coronavirus.html>. Acesso em: : 13 maio 2020.

PÚBLICO. Coronavírus: quarentena nas favelas do Brasil agrava pobreza em apenas uma semana. Público, 25 mar. 2020. Disponível em:

$<$ https://www.publico.pt/2020/03/25/mundo/noticia/coronavirus-quarentena-favelas-brasilagrava-pobreza-apenas-semana-1909380>. Acesso em: 13 maio 2020.

REUTERS. Governo vai discutir fim do regime de partilha do pré-sal, diz ministro. R7, 06 nov. 2019. Disponível em: <https://noticias.r7.com/economia/governo-vai-discutir-fim-doregime-de-partilha-do-pre-sal-diz-ministro-06112019>. Acesso em: 12 maio 2020. 
Rev. Interd. em Cult. e Soc. (RICS), São Luís, v. 6, n. 2, p. 28-49, jul./dez. 2020 ISSN eletrônico: $2447-6498$

RODRIGUES, Rodrigo; BORGES, Beatriz; FIGUEIREDO, Patrícia. Morumbi tem mais casos de coronavírus e Brasilândia mais mortes; óbitos crescem $60 \%$ em uma semana em SP. G1, 18 abr. 2020. Disponível em: <thttps://g1.globo.com/sp/saopaulo/noticia/2020/04/18/morumbi-tem-mais-casos-de-coronavirus-e-brasilandia-maismortes-obitos-crescem-60percent-em-uma-semana-em-sp.ghtml>. Acesso em: 14 maio 2020.

SAKAMOTO, Leonardo. Covid-19: Taxar super-rico traria $\mathrm{R} \$ 272$ bi contra crise, dizem entidades. Universo Online, 23 mar. 2020. Disponível em:

$<$ https://noticias.uol.com.br/colunas/leonardo-sakamoto/2020/03/23/coronavirus-taxar-superrico-trara-r-272-bi-contra-crise-dizementidades.htm?fbclid=IwAR15xHIDqIdKM1mtGnPcNpfJb6Tt-ByswPRwelfvwkf6S44fTyW2AspdN8>. Acesso em: 13 maio 2020.

SANDES, Arthur. Com mais de mil mortes em um dia, Brasil tem um óbito a cada 73 segundos. Universo Online, 19 maio 2020. Disponível em:

<https://noticias.uol.com.br/saude/ultimas-noticias/redacao/2020/05/19/covid-19-mortes-porsegundo-no-brasil.htm>. Acesso em: 14 maio 2020.

SANTOS, Boaventura de Sousa. A cruel pedagogia do vírus. Coimbra, Almedina, 2020. SANTOS, Boaventura de Sousa. Para além do pensamento abissal: das linhas globais à ecologia dos saberes. In: Epistemologias do Sul.org. SANTOS, Boaventura de Sousa; MENESES, Maria Paula. Coimbra, Almedina, 2009.

SHALDERS, André. Cargos que Bolsonaro negocia com centrão têm mais de R \$ 10,6 bilhões 'livres' para investir em 2020. Universo Online, 29 abr. 2020. Disponível em: $<$ https://noticias.uol.com.br/ultimas-noticias/bbc/2020/04/29/cargos-que-bolsonaro-negociacom-centrao-tem-mais-de-r-106-bilhoes-livres-para-investir-em-2020.htm>. Acesso em: 14 maio 2020.

SOARES, Manuela Goucha. Covid-19. China quer que Brasil peça desculpas das afirmações "racistas" do ministro da Educação. Expresso, 07 abr. 2020. Disponível em:

$<$ https://expresso.pt/coronavirus/2020-04-07-Covid-19.-China-quer-que-Brasil-pecadesculpas-das-afirmacoes-racistas-do-ministro-da-Educacao>. Acesso em: 14 maio 2020.

UNIVERSO ONLINE. Damares: poucos moradores de rua têm covid, pois ninguém pega na mão deles. Universo Online, 07 maio 2020. Disponível em:

$<$ https://noticias.uol.com.br/saude/ultimas-noticias/redacao/2020/05/07/damares-poucosmoradores-de-rua-tem-covid-pois-ninguem-pega-na-mao-deles.htm>. Acesso em: 14 maio 2020.

UNIVERSO ONLINE. 'Gripezinha': leia a íntegra do pronunciamento de Bolsonaro sobre covid-19. Universo Online, 24 mar. 2020. Disponível em: $<$ https://noticias.uol.com.br/politica/ultimas-noticias/2020/03/24/leia-o-pronunciamento-dopresidente-jair-bolsonaro-na-integra.htm>. Acesso em: 14 maio 2020.

URIBE, Gustavo; BRAGON, Ranier. Em retaliação a PT, Cunha ameaça deflagrar impeachment de Dilma. Folha de São Paulo, 02 dez. 2015. Disponível em: <http://www1.folha.uol.com.br/poder/2015/12/1714020-em-retaliacao-a-pt-cunha-ameacadeflagrar-impeachment-de-dilma.shtml>. Acesso em: 14 maio 2020. 
Rev. Interd. em Cult. e Soc. (RICS), São Luís, v. 6, n. 2, p. 28-49, jul./dez. 2020 ISSN eletrônico: $2447-6498$

VALOR ONLINE. Coronavírus é mais letal entre negros no Brasil, apontam dados do Ministério da Saúde. G1, 11 abr. 2020. Disponível em:

<https://g1.globo.com/bemestar/coronavirus/noticia/2020/04/11/coronavirus-e-mais-letalentre-negros-no-brasil-apontam-dados-do-ministerio-da-saude.ghtml>. Acesso em: 14 maio 2020 .

VILLAS BÔAS, Bruno. Nas favelas, 71\% apoiam quarentena. Valor Econômico, 09 abr. 2020. Disponível em: <https://valor.globo.com/brasil/noticia/2020/04/09/nas-favelas-71apoiam-quarentena.ghtml>. Acesso em: 14 maio 2020. 